\title{
Green road evaluation system and its progression route -Case study of Hubei province, China
}

\author{
Xueping Chen ${ }^{1 *}$, Sihua Bai ${ }^{2}$, Yangang Yang ${ }^{1}$, Li Jian ${ }^{1}$, Jialin Yao ${ }^{1}$, Shuohan Gao ${ }^{1}$, Qiong Wu and Yaping Kong ${ }^{1}$ \\ ${ }^{1}$ China Academy of Transportation Science, Beijing, 100029, China \\ ${ }^{2}$ Danjiangkou Municipal Transportation Bureau, Hubei Province, 442706, China
}

\begin{abstract}
In view of the lack of coordination or guidance of green road concept and relevant evaluation to encourage sustainability, we redefined the concept of green road and its characteristics, and then reviewed some cross-sector targets of various departments related to green development. The history of green road related policies and studies were reviewed, and a green road evaluation indices system were established with 2 broad categories-compulsory and selective. The compulsory category contains 8 indices; and the selective category includes 76 indices, which are divided into 7 categories and 31 subcategories, covering design, construction and operation. In order to improve the evaluation continually, rating principles, grading methods and main reference literature were given. Then we selected 30 indices and design in a questionnaire to trial evaluation, and 11 projects of Hubei province were collected and used for analysis. Finally, based on the longterm and complexity of the evaluation system, we suggest some key improving strategies of green road evaluation in China. The establishment of the green road system is an attempt to bridge the requirements of different departments, and to stimulate the progressing technology to meet various challenges.
\end{abstract}

\section{Introduction}

Concentrated by energy consumption and land utilization, the mode of transport development is highly related to the sustainability. Green road evaluation is an indispensable tool for promoting sustainable transport. The planning, construction and operation of highway is of great significance to enrich the content of green and sustainable development, so the whole society attaches great importance to green transportation and green road construction evaluation at home and abroad. The Federal Highway Administration of the United States has developed the infrastructure self-evaluation system tool (INVEST) to evaluate the whole process of green transportation planning, design, construction and operation $^{[1]}$. In China, research mainly focused on urban green transportation system planning or green transportation management ${ }^{[2-3]}$. In terms of the concept and evaluation of green road, some scholars started from the evaluation of energy conservation and emission reduction of highway or energy conservation of tunnel operation [4-6]. Yunnan Province formulated a local standard "Green road evaluation standard" in 2013, and the Ministry of Transport (MOT) issued an industry standard "Green traffic facilities evaluation technical requirements Part 1: Green highway" in 2018. In general, there are many understanding and definition of green road, from energy conservation and emission reduction of transport to environment-friendly infrastructure construction. However, previous evaluation studies have rarely considered solving the current challenges of transportation and achieving the multi-requirements of crossing industry in an overall situation. Also, little attention was paid to the practicability of an evaluation system. Few case studies used regional assessment system to suggest improvements. We started this study from the definition of green road concept, and reviewed the crosssector targets of various departments related to green development, as well as the history of green road related policies and researches. The evaluation system was established, and a case study in Hubei province were carried.

\section{Basic concept and other foundation review}

\subsection{Definition of "green road"}

The concept of green road is closely related to the concepts of sustainable development and ecological civilization. "Green" means sustainable in nature, covering many aspects such as economy, society and environment. Although domestic scholars have different understandings of "Green Road", most of them emphasize that it should cover the whole process including planning, design, construction and operation to achieve environmental, economic and social sustainability ${ }^{[7-8]}$. Most evaluations focus on the design and construction of this facility, and greatly ignore the planning and operation requirements that really dictate the green level of the 
highway. Based on the reviews of relevant scholars at home and abroad in recent years, we define that green road should have the following three characteristics:

- combining the process of planning, designing, constructing and operating as a whole, focusing on not only its own resource and energy consumption, pollution discharge and other environmental impacts, but also the surrounding impacts, and realizing harmonious coexistence with nature.

- realizing the coordination between resource utilization, energy consumption, pollution discharge, ecological impact, operation efficiency and construction quality, and providing users with excellent service and quality;

- being better than the previous practice level in realizing sustainable development, meaning that green is a relative concept and needs to be improved continuously.

Based on this idea, green road evaluation should include green road planning, design and construction, operation management assessment. Green road planning evaluation is closely related to planning environmental impact assessment, but there are some differences. Planning environmental impact assessment is a part of green road planning evaluation. In addition, the impact of road planning on resource and energy use, energy conservation and emission reduction, economic development and other contents are indispensable for green road evaluation, but it is a weak link in current researches and practices. The realization of green development in these aspects is of great significance for the realization of the integration of highway construction and national green development.

\subsection{Review of cross-sector targets related to green development}

The whole society participates in the reform of changing development in recent years, while we are considering that comprehensive environment management of road network should at least include the following:

- National Plan for Developing Functional Zones, issued by the National Development and Reform Commission (NDRC);

- Land resources (especially farmland, forestry and grassland) protection and utilization, in the charge of the Ministry of Natural Resources (MNR);

- Coordination of tourism development planning, responsible by the Ministry of Culture and Tourism;

- Environmental protection areas (ecological red line) and other protection targets management, total amount control of pollutants and emission reduction targets, energy consumption and pollutants deduction of specific region, in the charge of Ministry of Ecology and Environment (MEE);

- Water and soil conservation, in the charge of the Ministry of Water Resources (MWR);

- Environment related standards, policies, specification published or issued by different governments or Standards Committee.

\subsection{Review of China green road related policies and research}

In the past 30 years, China's highway construction has been advancing rapidly. Under the "transportation guiding policy" of MOT, highway has been developing rapidly from a scale of 1.02 million $\mathrm{kms}$ in 1990, to 4.847 million $\mathrm{kms}$ in 2018. With the increasing challenges for highway construction during the progressing towards the remote and mountainous areas of more and more sensitive and fragile ecological environment, attention should be also more taken to the key action worked. In the paper, we review the main phrase of highway transportation, and summarize some key aspects related to green road:

- Before 2004: Highway greening, mainly slope greening and native plant utilization led by construction contractors;

- 2004-2010: Change of highway survey and design concept, symbolized by both the resource conservation and environmentally friendly design incorporated into the flexible highway design concept; design concept of "safety, environmental protection, comfort and harmony", landscape coordination;

- 2010-2015: Energy-saving and emission reduction of demonstration project of highway construction, when $\mathrm{CO}_{2}$ emission and standard coal saving were taken as important quantitative indices;

- 2015 to now: all-round development of green road pioneer demonstration project, highlighting the resources and environment conservation, ecological environment protection, pollution control, quality engineering construction.

The above action sponsored by the MOT set a good foundation for the evaluation for the framework, furtherly, we investigated some demonstration projects and reviewed the technologies related to specific indices. We also summarized main conflicts or gap of the reality and the green development demanding.

\section{Green road evaluation index system}

\subsection{Assessment framework}

Guided by the problems existing in the development of highway, combined with the requirements of the concept of green road, the evaluation system is comprised of two broad categories of indices including compulsory index and selective index, as being illustrated in table 1 and table 2 respectively. Compulsory indices are not involved into the grading subsequently, but only performing as a precondition. And there are 8 indices being required, see table 1 . The main body of selective indices is highly in consistent with the current common framework of demonstration projects in 5 categories' indices. We added additional 2 indices of "overall control" and "innovation and exploration" to make up for the deficiency of cross specialty. And altogether the evaluation system composed of 7 categories, 31 subcategories, 76 indices, see table 2 . 
Table 1 Compulsory indices for green road evaluation.

\begin{tabular}{lll}
\hline Categories & Subcategories & Indices \\
\hline Legal compliance & $\begin{array}{l}\text { Implementation of environmental } \\
\text { impact assessment system }\end{array}$ & $\begin{array}{l}\text { Environmental assessment and } \\
\text { environmental impact acceptance } \\
\text { documents compliance }\end{array}$ \\
& $\begin{array}{l}\text { Implementation of water and soil } \\
\text { conservation plan }\end{array}$ & $\begin{array}{l}\text { Acceptance document of water and soil } \\
\text { conservation }\end{array}$ \\
& $\begin{array}{l}\text { Implementation of geological disaster } \\
\text { \& acceptance }\end{array}$ & $\begin{array}{l}\text { Document for prevention and control of } \\
\text { geological disaster } \\
\text { Safety assessment of project planning } \\
\text { Document of project planning and design }\end{array}$ \\
& $\begin{array}{l}\text { Project energy saving plan } \\
\text { Protection of historical and cultural } \\
\text { resources }\end{array}$ & $\begin{array}{l}\text { Review of energy saving evaluation report } \\
\text { Project quality according the checking procedure } \\
\text { acceptance report }\end{array}$ \\
Construction safety management & Project acceptance report (above excellent) \\
& & Safety control effect \\
\hline
\end{tabular}

Table 2. Selective indices for Green road Construction Assessment.

\begin{tabular}{|c|c|c|}
\hline Categories & Subcategories & Indices \\
\hline \multirow[t]{5}{*}{ Overall control } & Sensitive target avoidance ${ }^{1}$ & $\begin{array}{l}\text { Avoidance and protection of ecologically red } \\
\text { line } e^{1, q} \\
\text { Avoidance and protection of socially } \\
\text { environmental sensitive targets }{ }^{1}\end{array}$ \\
\hline & \multirow[t]{2}{*}{$\begin{array}{l}\text { Common sharing traffic } \\
\text { corridor or facility }\end{array}$} & $\begin{array}{l}\text { Sharing highway service facility with adjacent } \\
\text { transfer project }{ }^{1, \mathrm{q}}\end{array}$ \\
\hline & & $\begin{array}{l}\text { Sharing highway corridor with adjacent transfer } \\
\text { project }^{1, \mathrm{q}}\end{array}$ \\
\hline & \multirow[t]{2}{*}{ Landform protection } & High filling and deep excavation control ${ }^{1 \mathrm{ab}, \mathrm{q}}$ \\
\hline & & Filling and excavation balance control ${ }^{1 \mathrm{ab}, \mathrm{q}}$. \\
\hline \multirow{11}{*}{$\begin{array}{l}\text { Ecological } \\
\text { environment } \\
\text { protection }\end{array}$} & \multirow{4}{*}{$\begin{array}{l}\text { Vegetation protection and } \\
\text { restoration }\end{array}$} & Plant protection (turf) and utilization $1,3, \mathrm{q}$ \\
\hline & & Design and establishment of native plants $\mathrm{s}^{1,3, \mathrm{q}}$ \\
\hline & & Landscape design and construction $1,3, \mathrm{q}$ \\
\hline & & Vegetation recovery rate ${ }^{1,3}$ \\
\hline & Wildlife protection & Habitat connectivity ${ }^{1,3, q}$ \\
\hline & \multirow{3}{*}{$\begin{array}{l}\text { Effect of soil and water } \\
\text { conservation }\end{array}$} & Temporary land utilization and restoration ${ }^{1,3, q}$ \\
\hline & & Restoration rate of disposal land ${ }^{1,3, q}$ \\
\hline & & Wasted soil and residue retention rate $\mathrm{r}^{1,3 \mathrm{ab}}$ \\
\hline & \multirow{3}{*}{$\begin{array}{l}\text { Water ecological } \\
\text { environment protection }\end{array}$} & Water habitat connectivity ${ }^{1,3}$ \\
\hline & & Application of ecological drainage design $n^{1,3, q}$ \\
\hline & & $\begin{array}{l}\text { Environment protection construction of pile } \\
\text { foundation of wading bridge } \mathrm{e}^{1,3, \mathrm{q}}\end{array}$ \\
\hline \multirow[t]{11}{*}{ Pollution control } & \multirow[t]{5}{*}{ Water pollution prevention } & $\begin{array}{l}\text { Wastewater collection and treatment during } \\
\text { construction production }{ }^{2, \mathrm{q}}\end{array}$ \\
\hline & & $\begin{array}{l}\text { Sewage collection or treatment from construction } \\
\text { activities }{ }^{2, q}\end{array}$ \\
\hline & & $\begin{array}{l}\text { Sewage collection and treatment of ancillary } \\
\text { facilities during operation } 1,3, \mathrm{q}\end{array}$ \\
\hline & & Hazardous chemicals pollution control ${ }^{1,3}$ \\
\hline & & $\begin{array}{l}\text { Purification treatment rate of road surface } \\
\text { runoff }^{1,3, \mathrm{q}}\end{array}$ \\
\hline & \multirow[t]{3}{*}{ Noise control } & Noise control effect of sensitive targets $1,2,3, \mathrm{q}$ \\
\hline & & $\begin{array}{l}\text { Vibration control and noise reduction resulting } \\
\text { from construction activities }{ }^{2, \mathrm{q}}\end{array}$ \\
\hline & & Application of ecological sound barrier ${ }^{1}$ \\
\hline & \multirow[t]{3}{*}{ " $3 \mathrm{~S}$ " of Solid waste } & Harmless treatment of domestic garbage $\mathrm{e}^{1,3, \mathrm{q}}$ \\
\hline & & $\begin{array}{l}\text { Comprehensive utilization of demolished buildings } \\
\text { in passageway } 1,3, \mathrm{q}\end{array}$ \\
\hline & & $\begin{array}{l}\text { Risk management and control of hazardous waste } \\
\text { storage leakage } \mathrm{e}^{1,3}\end{array}$ \\
\hline
\end{tabular}


Air pollution control

Light pollution control

Resource saving Land resource saving

Water resources conservation

Utilization of old road facilities

Recycling and reutilization of materials

Utilization rate of "cleaning products"

Energy saving and emission reduction

Facilities energy saving

Energy saving in construction and management

\section{Quality assurance}

Standardized construction
Construction dust control ${ }^{2}$

Non-traffic vehicle exhaust control ${ }^{2}$

Asphalt fume control ${ }^{2}$

Light pollution control of sensitive sections $s^{1,3}$

Lighting dazzle control of median belt ${ }^{1,3, \mathrm{~A}}$

Cultivated land saving ${ }^{1, \mathrm{q}}$

Efficiency of topsoil resources protection ${ }^{1,3, \mathrm{q}}$

Permanent and temporary usage $e^{1,3, \mathrm{q}}$

Sewage recycling rate of service area ${ }^{1,3, q}$

Construction waste water recycling rate ${ }^{2, \mathrm{q}}$

Reuse rate of sites rainwater runoff $f^{1,3, q}$

Pavement regeneration and utilization ${ }^{1,3, \mathrm{q}}$

Utilization ratio of subgrade materials ${ }^{1,3, \mathrm{q}}$

Utilization rate of traffic safety facilities ${ }^{1,3, q}$

construction materials $\mathrm{s}^{1,3, \mathrm{q}}$

Utilization of biological resources ${ }^{1,3}$

Formwork material utilization ${ }^{2, \mathrm{q}}$

Cleaning productivity of building materials ${ }^{1,3}$

Clean packaging of building materials $\mathrm{s}^{1,3, \mathrm{q}}$

Equipment and control ${ }^{1,3}$

Proportion of green buildings $\mathrm{s}^{1,3, \mathrm{q}}$

ETC lane coverage $\mathrm{e}^{1,3 \mathrm{~A}, \mathrm{q}}$

Clean energy utilization ${ }^{1,3, \mathrm{q}}$

Ratio of warm mixed asphalt pavement ${ }^{1,3, q}$

Energy saving and emission reduction of

construction technology and equipment $\mathrm{t}^{1,3, \mathrm{q}}$

Energy saving in management regime ${ }^{2,3}$

Standardization of structure design ${ }^{1,2, q}$

Standardization of site management (including

laboratory $)^{2, \mathrm{q}}$

Informatization and quality

management

Informatization management, $\mathrm{t}^{1,2, \mathrm{q}}$

Environmental management ${ }^{1,2,3 q}$

Life cycle management ${ }^{1}$

Quality control ${ }^{1,2,3}$

Tourism service

Green service area ${ }^{1,2,3, \mathrm{~A}}$

improvement

Integration of highway and tourism leisure ${ }^{1,3}$

Humanized service facilities ${ }^{1,3}$

Integration of road and surrounding community development ${ }^{1,3}$

Professional landscape design ${ }^{1,3}$

Durable and convenient

Long life pavement proportion ${ }^{1,3}$

Functional pavement application ${ }^{1,3}$

Proportion of steel structure bridge $\mathrm{e}^{1,3}$

Bridge and culvert maintenance convenience ${ }^{1,3}$

Guarantee and emergency

Normally maintaining rate of environmental protection facilities ${ }^{2,3}$

Emergency equipment and management ${ }^{2,3}$

Emergency responsible organization and plan $^{2,3}$

Innovation and
exploration

Team building

Science and technology

Multi professional team building ${ }^{1,3}$

Innovation technology utilization ${ }^{1,3}$

innovation

Pioneering and enterprising

Public participation

Quality-engineering creativity ${ }^{1,3}$ public satisfaction ${ }^{1,2,3}$

Note:

1. The up note number 1,2,3 show the index only suitable for design, construction and operation period respectively;

2. The letter "A" only suitable for expressway;

3. The letter "a", "b" and "c"; indices respectively used for mountainous area, hilly area and plain area, and "q" used for questionnaire in the following case study on Hubei province. 


\section{2 weight of the index and level grade}

\subsubsection{The determination of weights}

Weights are critical to both the country and the transport industry. We take the top indices weights of Green Development Assessment Method by national and provincial governments as a main reference value in the top layer. So far, the National Development and Reform Commission and Hubei Provincial Government all issued relevant policies and specific assessment system ${ }^{[9-10]}$. As for the subordinate index, the Analytic Hierarchy Process (AHP) is introduced based upon questionnaire of specialized experts of transport in the region to determine weights ${ }^{[11]}$.

\subsection{2level grade}

Assessment standards is the most complicated and timeconsuming process, involving a lot of investigation and literature reference. We graded the specific index by four levels and set a score of 8-10, 6-8,3-6 and below 3 for individual level. The benchmark is adopted for each level as following:

- achieve/take world-advanced management and technical practice, adopted by fully developed countries, if not have or not enough, adopted by fully regions across China;

- better than the basic requirements of national laws, regulations or standards in developed region, or better than the goal planning formulated by the government departments in specific index, or better than the typical cases and experience displayed by the green road demonstration projects;

- better than the previous level of the region for related indices, based upon mainly local practice or standards investigation;

- under the level listed above.

As for the specific rating method, we mainly based our system on previous review of the cross-sector targets related to green development. And we listed the reference literature or documents below each index for a sound support, providing a base for future improvements. By this criterion, we can roughly know the green level to each index, even with incomplete statistics for the whole.

\section{Case study of Hubei Province}

\section{1 brief background of the province for evaluation}

Hubei Province, located in the central plain of China, is renowned for "a province of thousand lakes", and is also the location of the famous Three Gorges Dam of the Yangtze River. Shennongjia Nature Reserve is incorporated into the human and biosphere conservation plan by UNESCO. And Wudang Mountain are also worldfamous tourist attractions and highly enriched biodiversity areas in Hubei. The economic development and environmental capacity of population and other natural resources are relatively typical in China. In the past, Shennongjia-Yichang highway, Shanghai-Chengdu West Expressway in Hubei section had played a leading role in the development of green technology. We selected Hubei province as a case study to implement and check the green road evaluation system, to summarize the problems faced by the province, and to find a solution.

We analyzed the road network of Hubei province using the tool of GIS, and divided the region into three categories' area according to terrain characteristics: mountain area, hilly area and plain area. Road network grade and density is shown in table 3 .

Table 3. Road network grade and density for different terrain in Hubei

\begin{tabular}{lcccc}
\hline categories & Area/ $\mathrm{km}^{2}$ & $\begin{array}{c}\text { Road density of expressway, } \\
\mathrm{km} / \mathrm{km}^{2}\end{array}$ & $\begin{array}{c}\text { National highway } \\
\text { density, } \mathrm{km} / \mathrm{km}^{2}\end{array}$ & $\begin{array}{c}\text { Total road network } \\
\text { density, } \mathrm{km} / \mathrm{km}^{2}\end{array}$ \\
\hline Mountain area & 80522.8 & 0.0220 & 0.0158 & 0.0378 \\
Hilly area & 43259.63 & 0.0338 & 0.0256 & 0.0594 \\
plain & 62137.7 & 0.0518 & 0.0271 & 0.0789 \\
\hline
\end{tabular}

\subsection{Questionnaire \& indices design and investigation}

\section{- Indices for questionnaire}

We chose 31 indices with an upper note letter " $q$ " as shown in table 2, considering these data would be easier collected by questionnaire. Questionnaires are designed and distributed form to transportation bureau of counties and states in Hubei province. We had a feedback of 13 road projects, 11 of which were filled effectively.

\section{- Results analysis}

The average score of 30 indices in the survey is 2.40 , with the highest score of 3.90 . According to the standards, there are 3 projects reaching the third class (i.e. more than 3 points), and 6 projects exceeding the average score, accounting for just half, see figure 1 . The classification index scores suggest not only the relatively low score of green construction related to each construction project, but also show a large difference between projects. Overall, the index values of ecological environmental protection and quality engineering are 3.67 and 4.70 respectively, followed by the index values of overall control and pollution control; and the index scores of energy conservation and emission reduction are the lowest. 


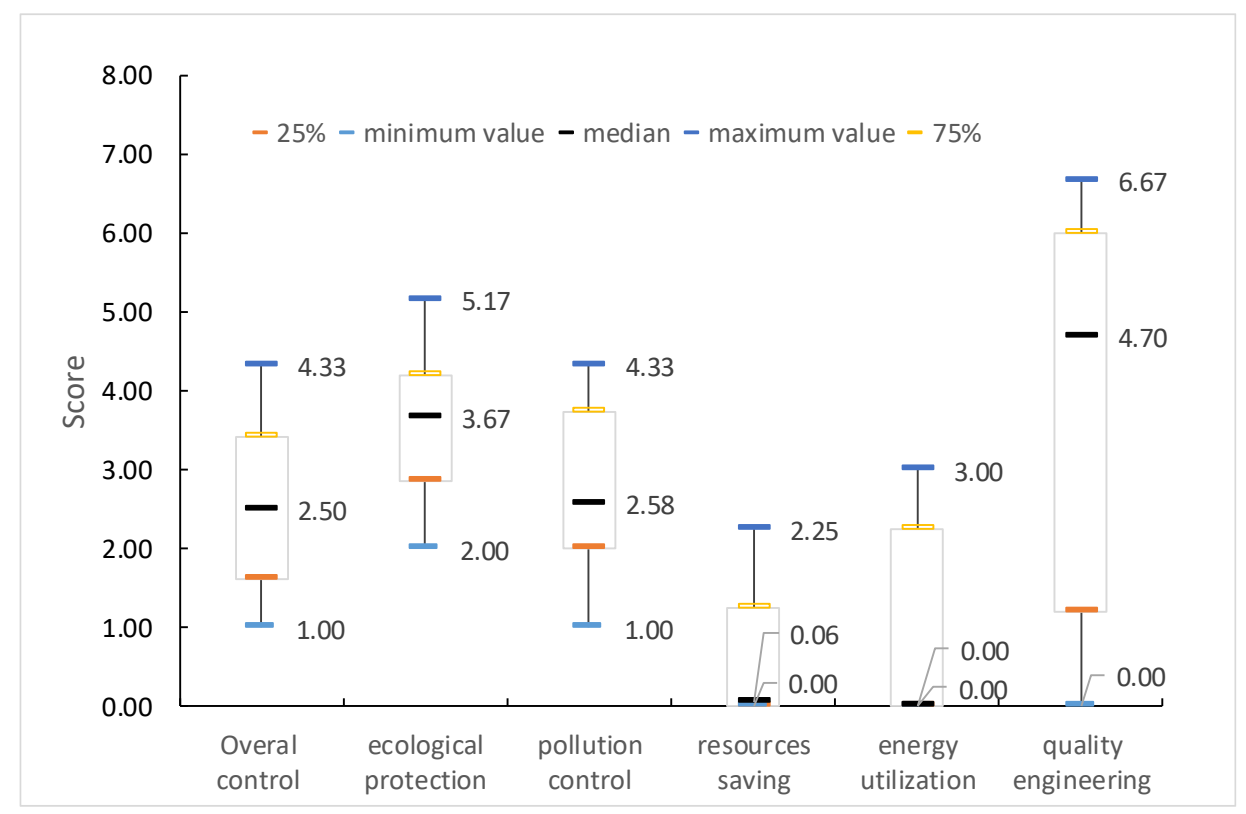

Figure 1 Score of the indices value of the investigation projects

Although 5 projects were upgraded on the base of previous roadbed, none of them had recycled the wasted asphalt to improve resource saving performance. No projects utilized warm mix asphalt pavement or the gas driving concrete-mixing-station, both of which are the key practices to reduce emission by MOT pioneer demonstration projects. No project had recycled the treated construction sewage and domestic sewage. The energy saving for tunnel lighting were led lights utilization, while intelligent control and any other applicable measures were in little usage. In summary, the investigation revealed that many practices suggested by the MOT were propelled poorly in the low-grade roads. Still, further investigation is needed to find the reason and solutions.

\section{Progressing route of the future discussion}

In this paper, we established a framework of green road evaluation system by a brief review of the development of the development history and other researches. The chosen evaluation indices could roughly reflect the main challenges China facing toward sustainability at present. Case study of Hubei province of some indices also suggest that the system is sensitive to reveal the main deficiency in the grass-roots road system management and hence can facilitate policy-making toward sustainability. There are some aspects we need to pay more attention to the progression route in the future, as being stated following.

Firstly, cross-sector indices and pertinent evaluation of efficient management or technologies still lag greatly behind the demand of reality. As for the management, the institutional mode or coordination between transportation departments and other departments, such as environment or resource/energy/economy need to be propelled to a more efficient status, which might depend upon the national institutional reform. These institutional challenges have been noticed by some scholars who study strategic assessment of road network ${ }^{[12-13]}$. Since we tended to set our grading benchmark according to the various normative documents of related departments and found that some of which might be not so reasonable or fully supported by research literature. Some indices, which is reasonable with international acceptance but could hardly be taken into practice in China. Taking road runoff pollution control as an example, a large number of studies have shown that the road runoff contains heavy metals, polycyclic aromatic hydrocarbons and other pollutants, and the green infrastructure (GI), and low impact development (LID) and best management measures(BMP) and even buffer management policies have been used extensively and effectively ${ }^{[14-15]}$. In China, the strict control utilization of roadside farmland of MNR, even lack of mechanism utilizing forestry and grassland, and the unwilling of additional fiscal expenditure of MOT, all make it difficult to carry the runoff treatment plan. So, our grading standards primarily aimed to encourage practice in intensive land such as service centre, interchange area, and the highway nearby the sensitive waters, combining the requirements of hazardous chemical management by the MEE.

Secondly, the indices related to green development for transportation also need a scientific and carefully summary and the previous demonstration projects need a post evaluation. Hence, we could work out a mechanism to keep the action going by conscious action of project contractor or set mandatory requirements to them for a more sustainable development. In the past, the rapid development of transport entailed by lots of vague indices and evaluation method should be pondered and scrutinized again and be selectively absorbed into the current evaluation system, but lots of achievements have not been incorporated due to deficiency of the data and material acquisition. For example, the important series of amount of energy saving counting system, contributed by a group of experts in transport, which had played an important role in "the twelfth 5-year plan" period to 
determine financial assistance for the demonstration projects of typical low-carbon-project. Maybe the vast indices and data colleting method could be improved further by researchers to make them better. The road system demands progressed continually and rapidly, and the lower grade roads might play an important role in the future, so we wish the green road evaluation system could contribute actively to the process.

The evaluation system and case study accomplished in Hubei province suggest the definition of green road and the evaluation method is generally reasonable and are worthy of keeping improvement. The past definition of "green road" or "green highway" in China's previous research or MOT documents, did not clearly emphasis the characteristic "better than the previous practice", has been making it difficult to carry out evaluation and to encourage the improvement of road system due to lack of criterion. As we can also find that since there are huge regional differences of environmental, social and economic condition across China, and there is also big gap between expressway to lower grade road, which mean the past green practice or evaluation indices derived from expressway might hardly be suitable to extend to common national highway or other low grade roads. So, it remains a long way to go in the future.

\section{Acknowledgments}

Thanks to the organization of Hubei Provincial Highway Bureau, Danjiangkou Municipal Highway Bureau for their arduous contribution of case study in Hubei province. Many colleagues of our research team have also contributed to the many review or investigation but maybe not reflect in the authors list. Financial support: Science and technology project of Hubei Provincial Department of Transportation (Hubei Road Construction [2017] No. 80).

\section{References}

1. Cui S H, Bao G F . (2013). Study on evaluation index system of energy conservation and emission reduction in road transport industry $[\mathrm{J}]$. Forest engineering, 29: 142-14.

2. Lu H P. (2009)The way to realize urban green transportation [J]. Urban transportation, 7: 23-27.

3. Wang S, Zhang H Y, Feng Z H. (2018) Study on evaluation index system of green transportation development [J]. Comprehensive utilization of resources in China, 36: 183-186.

4. Yang B, Zhang Zhengqi, Zhang Huixian. (2014) Quantitative evaluation method for energy conservation and emission reduction of asphalt pavement $[\mathrm{J}]$. Highway transportation technology, 31 : 32-38

5. Zhang $\mathrm{H} \mathrm{T}$, Meng L. (2017) Energy saving and emission reduction evaluation system of Asphalt Pavement Based on LCA [J]. Shanxi architecture, 43: 186-188

6. Wang S F, Tu Y, Deng X. (2013) Evaluation index system of energy conservation and emission reduction in expressway tunnel operation [J]. Journal of railway engineering: 88-92

7. Zhang ZY, Wang ZH, Zhang Lian, Wang Shuai, Zeng Wei. (2018) China green highway construction and evaluation technology [J]. Journal of Chang'an University (natural science edition), 2018,38: 76-86

8. Wang X Q, Zhang L, Wang Z H. (2016) Study on the evaluation index system of green highway $[\mathrm{J}]$. Road building machinery and construction mechanization, 33: $34-38$

9. The Development and Reform Commission, 2016. The green development index system and the assessment target system of ecological civilization construction. http://www.gov.cn/xinwen/201612/23/content_5151575.htm

10. The Hubei Provincial Development and Reform Commission, 2017. Index system of green development in Hubei Province and assessment target system of ecological civilization construction in Hubei

Province.http://www.hubei.gov.cn/zwgk/hbyw/hbyw $\mathrm{qb} / 201707 / \mathrm{t} 20170713$ 1016743.shtml

11. Saaty T. L. (2004) Decision making - The analytic hierarchy and network processes (AHP/ANP), Journal of Systems Science and Systems Engineering 13:1-35.

12. Zhu Z, Wang H, He X U, et al. (2010) An alternative approach to institutional analysis in strategic environmental assessment in China[J]. Journal of Environmental Assessment Policy \& Management, 12:155-183.

13. Monteiro M B, do Rosário Partidário Maria, Louis M. (2018) A comparative analysis on how different governance contexts may influence Strategic Environmental Assessment[J]. Environmental Impact Assessment Review, 72:79-87.

14. Huber M, Welker A, Helmreich B. (2015) Critical review of heavy metal pollution of traffic area runoff: Occurrence, influencing factors, and partitioning $[\mathrm{J}]$. Science of the Total Environment, 541:895-919.

15. Tord Snäll, Joona Lehtomäki, Arponen A, et al. (2016) Green Infrastructure Design Based on Spatial Conservation Prioritization and Modeling of Biodiversity Features and Ecosystem Services[J]. Environmental Management, 57:251-256. 